\title{
DESIGNING AN AUTOMATIC MICROCONTROLLER-BASED DRYING MACHINE OF COFFEE BEANS
}

\author{
Derisma * | Afdholli Putra | Dodon Yendri
}

Dept. of Computer System, Universitas Andalas, Padang, Indonesia

\section{Correspondence}

*Derisma, Dept. of Computer Science, Universitas Andalas, Padang, Indonesia.

Email: derisma@fti.unand.ac.id

\section{Present Address}

Department of Computer System, Faculty of Information Technology, Universitas

Andalas Padang, 25163 Indonesia

\begin{abstract}
This research aimed to create an automatic microcontroller-based coffee bean drying machine without the support of sunlight to produce SNI-standardized coffee beans with small water content or amounted to $12 \%$. The appliance consists of a tubeshaped container with $50 \mathrm{~cm}$ length and $11 \mathrm{~cm}$ radius, soil moisture sensor, DS18B20 temperature sensor, heater, motor DC, relay two-channel, and Arduino Uno microcontroller. The drying works when soil moisture sensor detects $12 \%$ of water content from big coffee beans. The drying process is done by applying a heater to dry the coffee beans, and the motor DC is used as the rotator of the container to dry the coffee beans evenly. The temperature of the drying container is around $51^{\circ} \mathrm{C}-55^{\circ} \mathrm{C}$ because the surface of coffee beans will be damaged if the temperature is above $55^{\circ} \mathrm{C}$. When the water content of coffee beans is low or equal to $12 \%$, the drying process is terminated. The drying process of dense coffee beans ( $1 \mathrm{~kg}$ ) with $25.34 \%$ of initial water content takes 60 minutes with $11.74 \%$ of final water content as a result, While the drying process with the help of sunlight required approximately 310 minutes with $11.83 \%$ of final water content. It has been proved that the drying with the machine was faster than the drying process through sunlight.
\end{abstract}

\section{KEYWORDS:}

Arduino Uno Microcontroller, Coffee Beans, Drying Machine, Moisture Indicator, Moisture Sensor, Water Content

\section{1 | INTRODUCTION}

Coffee provides unique benefits for the well-being of the Indonesian people. Coffee is a valuable plant to ensure a sustainable economy for farmers in tropical and sub-tropical areas. Tropical and sub-tropical regions are the proper location for coffee cultivation ${ }^{11}$. Therefore, countries that dominate the world of coffee production are located in South America, Africa, and Southeast Asia. Indonesia is one of the largest coffee producers and exporters in the world. Indonesia is also among the four largest coffee producers and exporters in the world. Various obstacles have been experienced by Indonesian farmers to produce 
world-standard coffee beans ${ }^{2] 3}$. The coffee processing method can drastically change the quality and the end-taste of the product to be better or worse. By selecting the method that generates positive impacts toward quality, taste, and cost, coffee producers can optimize the potential of coffee as well as optimize the revenue of farmers gained from high-quality coffees 4 .

There are some coffee management processes during the post-harvesting period. According to Agriculture Ministry Regulation ${ }^{[5}$, post-harvesting management processes are divided into three; namely, Dry Process, Fully Washed, and Semi-Washed Process. Until present, the drying process is still performed naturally or traditionally, namely by drying under the sunlight, which requires a very long time and will produce a less-hygienic product ${ }^{16}$. The natural drying process of coffee beans through the help of sunlight requires 3 to 4 days of the drying process, which frequently inhibits farmers' work, therefore, coffee farmers were sometimes complaining about the unstable weather, especially during the rainy season. As a result, farmers often failed to dry their yields. The rain that falls continuously can grow mold on coffee beans. Thus, they get deteriorated.

During the drying process, the best water content for the coffee commodity is below $12 \%$. If the water content is above $12 \%$, thus, Aspergillus Ochraceous, Aspergillus Niger, and Penicillium molds would likely grow. These molds would grow quickly if the water content of the coffee is above $12 \%$. The observation result has indicated that most of the coffees produced in Indonesia conceive above $12 \%$ water content before determined as the export standard. A farmer and collector level, the typical water content is above $16 \%$. Even in some locations, the water content would reach $20 \%$ [ The solar-tub drying machine has been successfully designed and fabricated by Syah ${ }^{[8}$.

The result of the functional test has indicated that weather conditions more influence the variety of solar collector and dryer. The drying of coffee beans itself requires weeks. Therefore, coffee beans drying machine with a better drying rate is needed. The drying machine of coffee beans with the active solar-tracking system through the application of temperature and SHT11 radiation sensors has been developed ${ }^{9}$. The deficiency is that the humidity and temperature sensors experienced more errors when the received temperature exceeds the room temperature that, in general, reaches $45^{\circ} \mathrm{C}$. The final quality of coffee depends on the curing of the cell membrane of coffee beans, which might get deteriorated during the drying process $\stackrel{10}{ }$. For the drying temperature set at $35^{\circ} \mathrm{C}$, the increasing drying rate caused the degradation of the coffee's natural sensory quality. For the drying temperature set at $45^{\circ} \mathrm{C}$, the drying rate's degradation is described by thermal decay and the effect of unclear drying rate ${ }^{10]}$. The farmers will no longer have to use the traditional method if they use this coffee bean drying machine. Thus, the needs of farmers can be fulfilled.

Such as accelerating the drying process, acquiring a good quality of coffee, also saving space. In this process, the masses of coffee beans in after and before the drying process can be discovered by using a useful system to reveal the water content in coffee beans as the drying process that reaches accurate dry rate to produce a good standard of coffee beans to improve food products. One of the technological developments is in the Arduino Uno microcontroller field that has been applied in various sectors. Nimrotham ${ }^{111}$ experimented on a microcontroller unit (MCU) to control relative humidity and temperature in the chamber for drying red chili. Therefore, this technology development, which became the next background of the problem in which the implementation of Arduino technology on industrial sector especially on the coffee factory is expected to be able of providing better effectivity and time efficiency during the drying process of coffee beans to facilitate farmers in producing good quality coffee. Previously, the drying machine of these coffee beans was shaped like an oven and equipped with a heating furnace below it, and its tool has not provided with microcontroller and sensors $\overline{8}$.

In the next research, the drying machine of coffee beans required supplement of energy from direct combustion of biomass in the form of coffee processing waste, namely the coffee husk to improve the performance of the tool and determined by weather ${ }^{\sqrt[8]{6}}$. In the next study, the drying machine of coffee beans controlled by a microcontroller by setting the temperature on the time-based drying tub ${ }^{[12]}$. The latest research about the coffee drying machine used an active solar-tracking system to support microcontroller and temperature sensors and ignore humidity ${ }^{[9}$. Of the four studies above, two studies ${ }^{[8] 9]}$ required sunlight to dry coffee beans. The ${ }^{[12]}$ study controlled the temperature on the coffee drying tub. Therefore, building an automatic drying machine of coffee beans without sunlight with even drying process has gained the author's interest. The goals to be achieved in this research were to design an automatic microcontroller-based drying machine of coffee beans without the help of sunlight and utilizing sensors to produce SNI-standardized coffee beans. Then, compare the drying time of coffee beans between the automatic drying machine and the drying process through sunlight while the benefit of this research is to produce coffee beans with $12 \%$ of maximum water content without requiring the drying process under the sunlight and very spacious room, therefore, coffee beans can be manufactured practically and securely. The objectives and contributions provided in this research are: (1) 


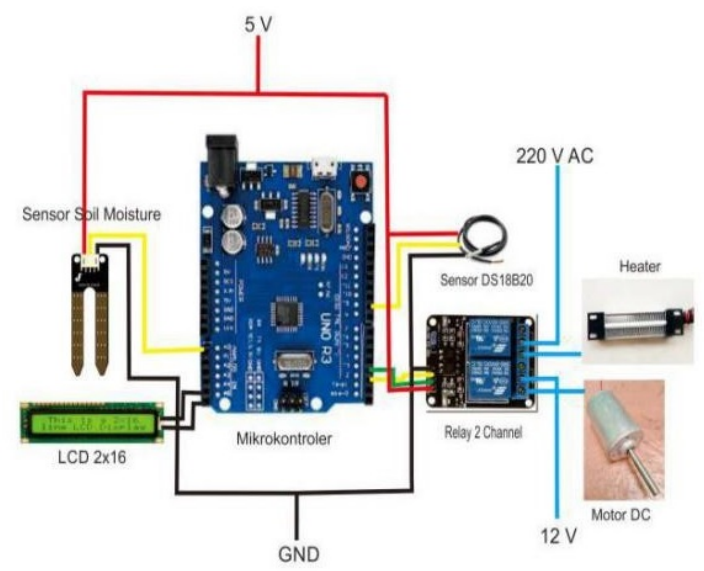

FIGURE 1 Series of hardware.

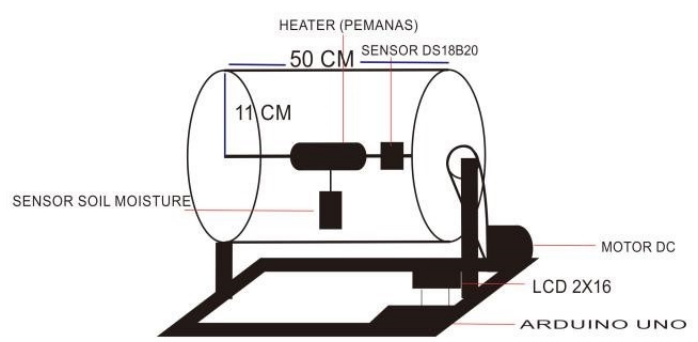

FIGURE 2 The mechanic of hardware.

Creating automatic drying machine of coffee beans $\mathrm{h}$ can be used for household level; (2)Discovering the duration in producing SNI-standard, coffee beans namely low water content or equal to 12\%; (3)Accelerating the drying process of coffee beans by paring the duration of the drying process of coffee beans between the automatic drying machine of coffee beans and the drying with the help of sunlight.

\section{2 | METHOD}

This research was using an experimental research method by connecting components and tools with different characteristics. Those components and tools were soil moisture sensor, DS18B20 sensor, motor DC, relay, LCD, heater, and Arduino Uno. DS18B20 temperature sensor with waterproof ability is fit to be used in measuring temperatures in hard or wet places. The drying system used an electrical heater because it will be functioned for the household level. In this research, the tools were tested to discover whether the provided input is consistent with the expected outcome. The object in this research was coffee beans that will be dried through heater with $55^{\circ} \mathrm{C}$ temperature, and the drying tub was rotated through motor DC for the water content in coffee beans to become $12 \%$, and for the drying, the result will be even.

Three voltages to supply the circuit are: (1) the source from 12 VDC power supply to provide Arduino Uno and motor DC; (2) a 5 VDC voltage from the output of Arduino to supply soil moisture sensor, DS18B20 sensor, and LCD; (3) a 220 VAC of energy to supply the power supply and the heater. According to Figure 1. as the series of hardware on the designing of an automatic microcontroller-based drying machine of coffee beans, it can be known that this tool is designed for automatic coffee bean drying. Figure 2 shows the drying container will be made as a tube with $11 \mathrm{~cm}$ of radius and $50 \mathrm{~cm}$ of length. Small holes will be made on the tube's surface of the container. These tiny holes are functioned as the entry and the exit of air on the container. This tool works if the soil moisture sensor detects more than $12 \%$ of water content in coffee beans. Thus, the microcontroller would give the command to motor DC and heater to conduct the drying process. Motor DC is functioned as the tool to rotate the container to even the coffee drying process. The heater is set with $55^{\circ} \mathrm{C}$ of temperature on the container. Thus, the heater will be turned off until the temperature drops to $50^{\circ} \mathrm{C}$. After the temperature reaches $51{ }^{\circ} \mathrm{C}$, therefore, the heater will be turned on again to perform the drying process. Then, if the water content of coffee beans has reached $12 \%$; thus, the machine will stop.

The descriptions of the flowchart of the coffee drying process in figure 3 as follows: initialization is conducted toward what required from the entire system. Next, the soil moisture sensor reading is performed when the drying container is steady or not rotating. Therefore, the water content read by the sensor will be constant. So, the selection of condition is performed when the motor has been shut down, then, the water content of coffee beans will be read. The drying process occurs when the water content of coffee beans is more than $12 \%$. Thus, the heater and motor DC will turn on. The DS18B20 temperature sensor detects the temperature on the drying container. If the temperature has reached $55^{\circ} \mathrm{C}$, the heater will go off and get back online when the temperature drops to $51^{\circ} \mathrm{C}$. A Thirty-second delay is given to make the temperature drops. If the drying process has been 


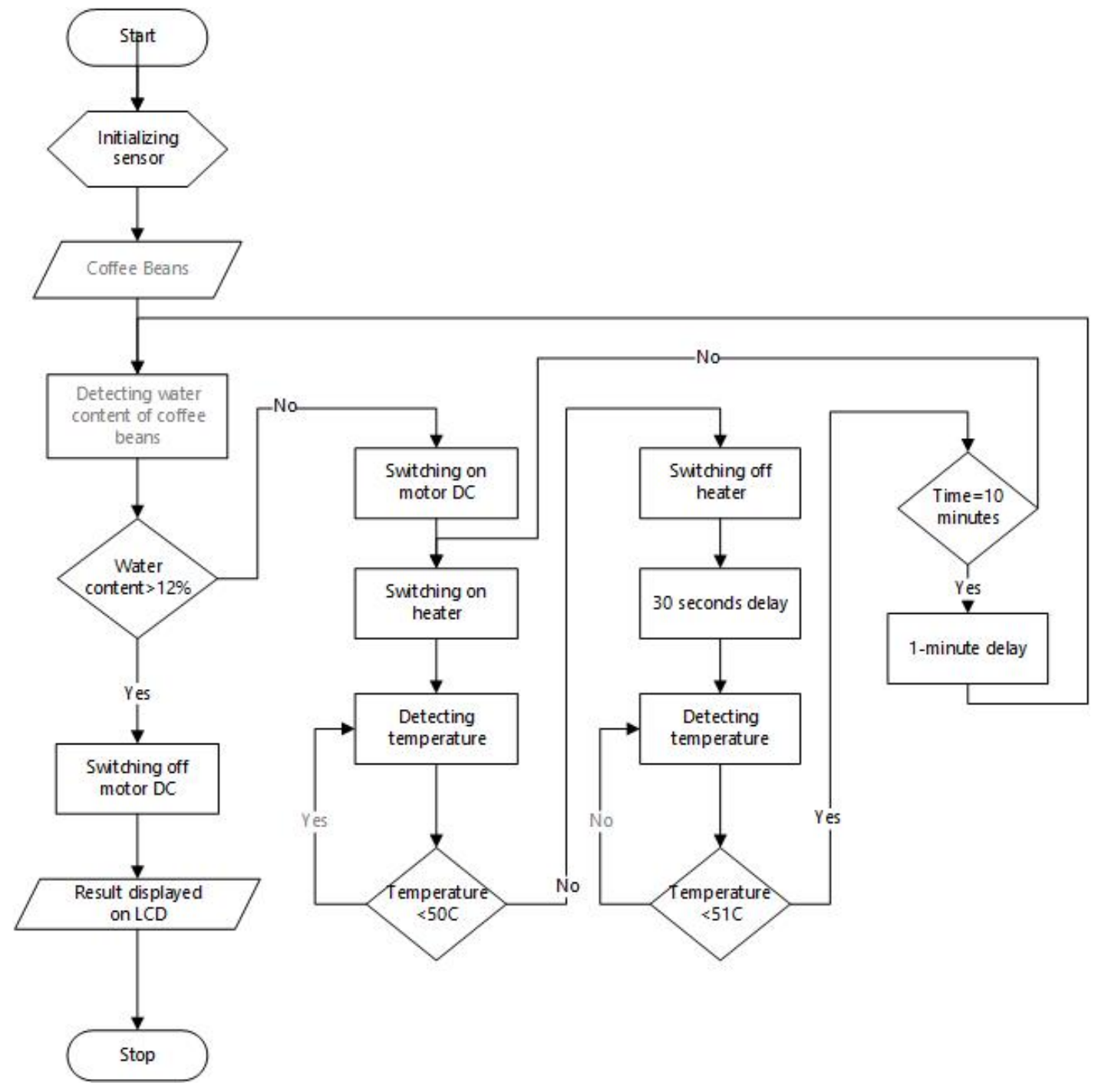

FIGURE 3 Flowchart of the drying process of coffee beans.

conducted for 10 minutes. Thus, the 1-minute delay is provided; if it is not, the drying process is performed. One minute delay is carried out to prevent any errors during the detection of coffee beans' water content. The water content of coffee beans and the temperature of the container are displayed through LCD. When the water content of coffee beans is low or equal to $12 \%$; thus, the drying process is finished.

\section{3 | RESULTS AND DISCUSSION}

\section{1 | The Application of Hardware}

The application of hardware consists of a tub-like vessel with $50 \mathrm{~cm}$ of length and $11 \mathrm{~cm}$ of radius and several components such as Arduino Uno microcontroller, DS18B20 temperature sensor, soil moisture sensor, motor DC, heater and 2x16 LCD. Figure.4 shows the front-look of the hardware application result. 


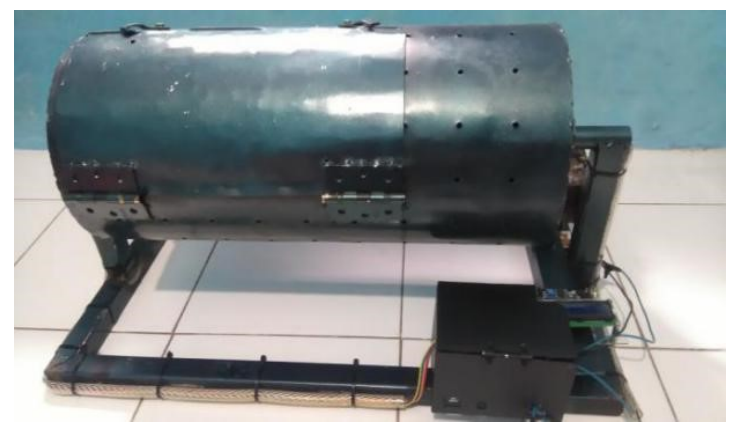

FIGURE 4 The mechanic of the tool.

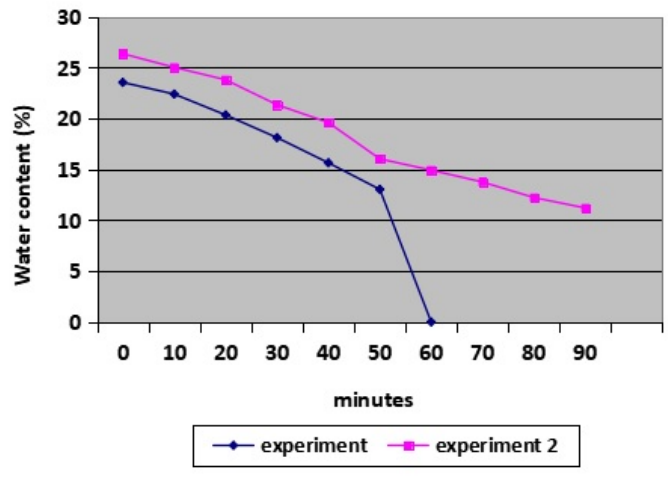

FIGURE 5 The duration test of the drying process of 3 $\mathrm{Kg}$ coffee beans.

\section{2 | Testing}

The testing of the drying process duration on an automatic coffee drying machine was aimed to compare the duration between the drying process on the machine and the help of sunlight. The testing was conducted through the drying with two attempts for $3 \mathrm{Kg}$ weight and two attempts for $6 \mathrm{Kg}$ of coffee beans. On the machine, the water content of coffee beans was checked every 10 minutes, so when 10 minutes have passed, the motor DC stopped, so the reading of water content can be measured.

\subsection{The Duration Test of the Drying Process on Automatic Drying Machine}

According to the test result, the first test on $3 \mathrm{~kg}$ of coffee beans has 23.56 of initial water content. However, in the 60 th minute, $0 \%$ of water content was acquired because the soil moisture sensor did not hit the coffee beans, and the drying machine of coffee beans stopped because the water content was lower than $12 \%$. When the sample of coffee beans was taken and measured on its water content by using grain moisture while it has $10.19 \%$ of water content. The second test on $3 \mathrm{~kg}$ of coffee beans has $26.75 \%$ of initial water content. The drying process was performed for 90 minutes to reach $<12 \%$ of water content. The final water content of $3 \mathrm{~kg}$ coffee beans on the second test was $11.21 \%$. The graphic of the duration of the drying process of $3 \mathrm{~kg}$ of coffee beans can be seen in Figure 5.

The first test on $6 \mathrm{~kg}$ of coffee beans resulted in $23.81 \%$ of initial water content. The drying process was performed for 170 minutes to reach $<12 \%$ of water content. During the drying process, the fluctuation of water content was due to the large quantity of coffee beans. Thus, the water content of coffee beans has not been distributed evenly. However, in the 60th minute, the water content has no fluctuation. The rotation of the container caused this condition, so the coffee beans were adequate. The final water content of $6 \mathrm{~kg}$ coffee beans on the first test was $11.73 \%$. The second test on $6 \mathrm{~kg}$ of coffee beans has $26.75 \%$ of initial water content. The drying process was performed fro 200 minutes to reach $<12 \%$ of water content. During the drying process, similar to the first test, the fluctuation was caused by a large quantity of coffee beans. Thus, the coffee beans were not distributed evenly. The final water content of $6 \mathrm{~kg}$ of coffee beans on the second test was $11.43 \%$. The graphic of the duration of the drying process of $6 \mathrm{~kg}$ of coffee beans can be seen in Figure 6.

\subsection{The Duration Comparison Test of the Drying Process between Automatic Drying Machine and Sunlight}

The testing was performed by comparing the duration between the drying time of coffee beans through the use of the machine and the drying process with the help of sunlight. The weight of the tested coffee beans was $1 \mathrm{Kg}$, and the initial water content of coffee beans was $25.34 \%$. Then, the test was applied to the drying machine and the drying process through sunlight. These are the results of the testing. It can be concluded that the duration of the drying process of coffee beans with an automatic drying machine required 60 minutes with $11.74 \%$ of final water content while the drying process with the help of necessary sunlight 310 


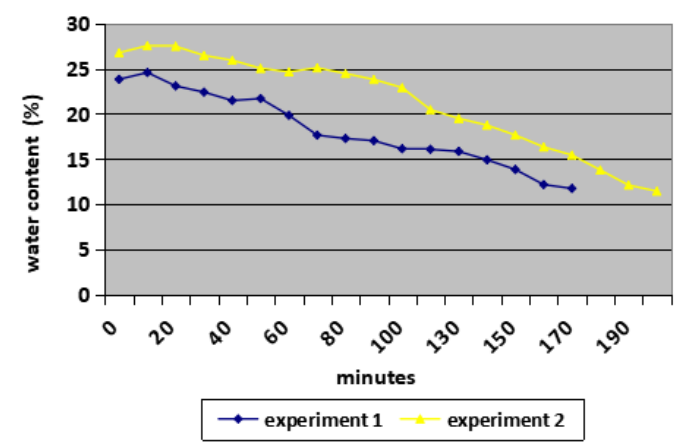

FIGURE 6 The duration test of the drying process $6 \mathrm{~kg}$ coffee beans.

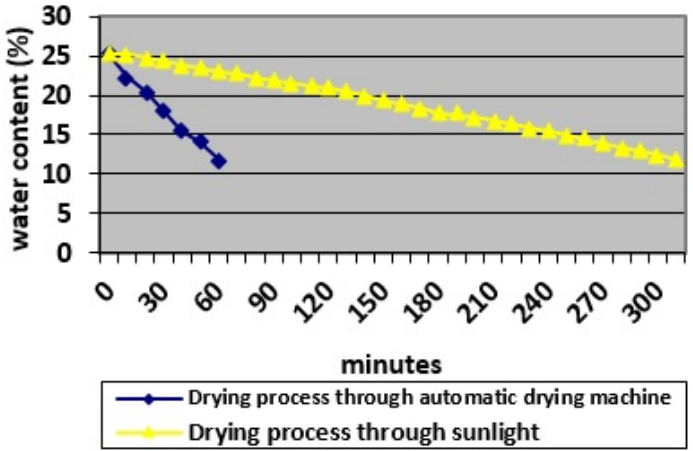

FIGURE 7 The drying process with machine and with the help of sunlight.

minutes with $11.83 \%$ of final water content. It can be seen that the drying temperature was profoundly affecting the drying time on coffee beans. The drying temperature can be set on the drying machine, while the drying process with the help of sunlight depended on the weather. The comparison graphic between the drying with the machine and the drying with the help of sunlight can be seen in Figure 7.

\section{4 | CONCLUSION}

According to the conducted research and tests, we can conclude the following. First, the design of the automatic microcontrollerbased drying machine of coffee beans can function properly in producing the water content during the drying process. The design uses the input of soil moisture sensor to measure the water content of coffee beans and DS18B20 sensor to adjust the tub temperature. The quantity of water being dried was up to $10.9 \%, 11.21 \%, 11.73 \%$, and $11.43 \%$. This result is parallel to the SNI-standardized coffee beans that once. Second, the duration of the drying process of coffee beans with an automatic drying machine required approximately 60 minutes, with $11.74 \%$ of final water content. The drying process with sunlight's help required about 310 minutes and removed water up to $11.83 \%$. It has been proved that the drying with the machine was faster compared to the drying process through sunlight.

To improve the deficiency, some improvements are required for better performance of tools. Several suggestions are provided as follows: the future studies should add methods in the drying process of coffee beans to accelerate the drying process and then replacing motor DC into motor AC to be able to rotate the tub with coffee beans on a large scale.

\section{References}

1. Novita, E, Syarief, R , Noor, E , \& Mulato S. Peningkatan Mutu Biji Kopi Rakyat dengan Pengolahan Semi Basah Berbasis Produksi Bersih. Argoteknologi 2010;4(1):76-90.

2. Poltronieri P, Rossi F. Challenges in Specialty Coffee Processing and Quality Assurance. Challenges 2016;7(2):19.

3. Mayrowani H. Kebijakan Penyediaan Teknologi Pascapanen Kopi dan Masalah Pengembangannya. Forum Penelitian Agro Ekonomi 2013;31(1):31.

4. C M Kopi, O Z Price, P Teknis, S Echo, P Abram, Riley D. Catatan Penting tentang Pemanenan dan Cara Mengolah Kopi. ECHO Asia Note Articles 2016;29.

5. Kementrian Pertanian, Kementrian Pertanian RI, editor, Pedoman Paska Panen Kopi, no 52/Permentan/OT.140/9/2012. Kementrian Pertanian, Republik Indonesia; 2012. http://perundangan.pertanian.go.id/admin/p_mentan/Permentan\%2052-2012\%20PASCAPANEN\%20KOPI.pdf 
6. Suryono AF, Hoten HV. Kaji Eksperimental Perbandingan Performansi Mesin Pendingin Kompresi Uap dengan Menggunakan Pipa Kapiler dan Katup Ekspansi. Jurnal TEKNOSIA 2009;2(6):34-39.

7. Susila WR. Targeted Study of the Arabica Coffee Production Chain in North Sumatra (The Mandheling Coffee). Jakarta: Food and Agriculture Organization, United Nations; 2005.

8. Syah H, Agustina R, Moulana R. Rancang Bangun Pengering Surya Tipe Bak untuk Biji Kopi. Rancang Bangun Pengering Surya Tipe Bak Untuk Biji Kopi 2016;9(1):25-39.

9. Faizin AQ. Rancang bangun sistem monitoring suhu dan radiasi pada mesin pengering biji kopi berbasis penjejak matahari aktif dengan mikrokontroler ATMEGA32. Final project, Institut Teknologi Sepuluh Nopember; 2017.

10. Borem FM, Isquierdo EP, Alves GE, Ribeiro DE, Siqueira VC, Taveira JHDS. Quality of Natural Coffee Dried Under Different Temperatures and Drying Rates. Coffee Science 2018;13(2):159-167.

11. Nimrotham C, Songprakorp R, Thepa S, Monyakul V. Experimental Research of Drying Red Chili by Two Methods: Solar Drying and Low-Temperature System Drying. Energy Procedia 2017;138:512-517. https://doi.org/10.1016/j.egypro.2017. 10.237

12. Javanmard M, Abbas KA, Arvin F. A Microcontroller-Based Monitoring System for Batch Tea Dryer. Journal of Agricultural Science 2009 nov;1(2):p101.

How to cite this article: Derisma D., Putra A., Yendri D. (2020), Designing An Automatic Microcontroller-based Drying Machine of Coffee Beans, IPTEK The Journal of Technology and Science, 31(1):11-17. 